.

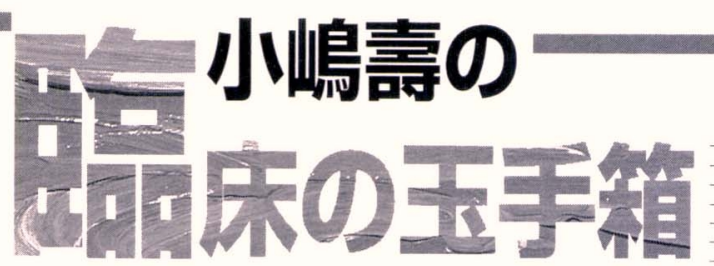

\title{
何か変だな,クラウンセット? (6)
}

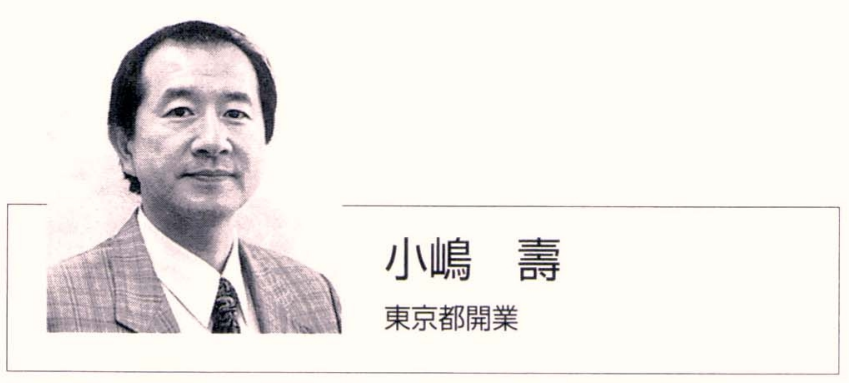

クラウン製作技工操作（3）

\section{1. 埋 没}

その昔, 私が学生のときに鋳造冠の宿題が出て, 私の友人 は空き缶に針金のひもを通してぶら下げられるようにし， 缶の中の焼けた鋳造リングの上で金属を溶かし，おもむろ に空き午をまわして鋳造するんだ，という話を聞いたこと がある、確かにそんな方法でも鋳造はできないことはない かもしれないが，金属が酸化されたり，すが入ったり，引 かれてしまったりということ以外に，鋳造体のささやかな 精度ということに対しても問題のあるところである。鋳造 体がまったくどんぴしゃで，寸分たがわない精度にできあ がる，などということは稀にでもありえないことである。

このような中で鋳造体のささやかな精度を確保するため にはどうすればよいのか？考え方と方法手順, そして機械 や器材を選ぶことが大変大切なことなのである。機械や器 材ではそんなに変化はないが, 手法は人により様々である。

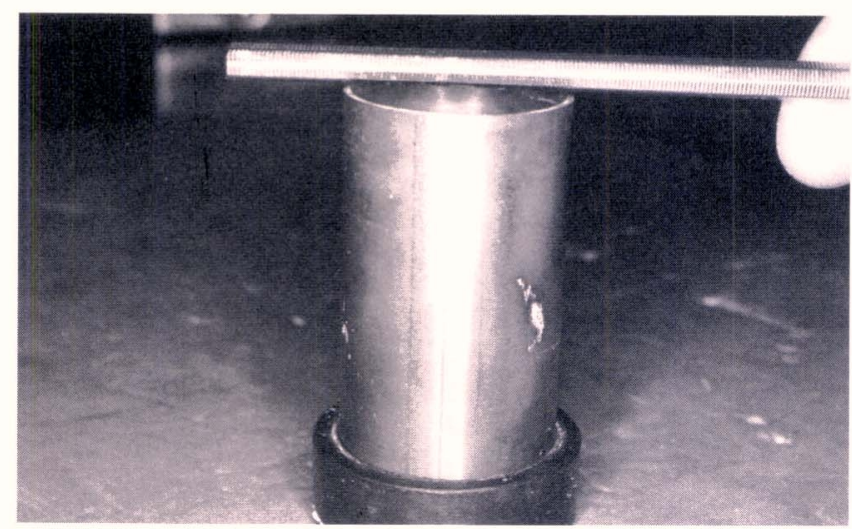

図 1 鋳造リングは $5.5 \mathrm{~cm}$ の長さのものを使い,パターンは緑か5 $5 \mathrm{~mm}$ 以上離す

\section{2. 埋没の準備}

鋳造方法を遠心鋳造ではなく真空圧流し込みの機械で行 っている関係上からもあり, 鋳造リングは $5.5 \mathrm{~cm} の$ 縦に長 めのリングを使っている。この鋳造リングに専用の円錐台 をつけ，その山錐台にワックスパターンをスプルー線でつ けて鋳造するのである。専用のぴったりした円錐台を使う ことも大切であるが, ワックスパターンの位置や高さが大 変に重要である.鋳造の原理から考えて,リングの中央また は中心部にワックスパターンを位置づけてはいけない。鋳 造リングを横から見たときの対角線の交点, つまりリング の中央部では炉に入れて焼成したときの温度が，いつまで も一番高い温度で保たれている場所であることは論を待た ない.この場所にパターンがあると, 鋳造時に鋳型の中に せっかく入った金属がいつまでも固まらずに流動性を保っ ているため, 先に冷えて固まったほうへ金属が引かれてし まう。そのため十分満足のいく鋳造体が得られなくなって しまうのである。そこでワックスパターンはリングの中央 部を避け, しかも表面から入った位置で埋没されなければ ならないのである。そうすれば鋳型に流れ込んだ金属のほ うから冷えて徐々に硬化していき, 中央部分のまだ流動性 のある金属に引かれなくてすむ.そのことから考えてもス プルーは太めのスプルーワックスを使うことが賢明である.

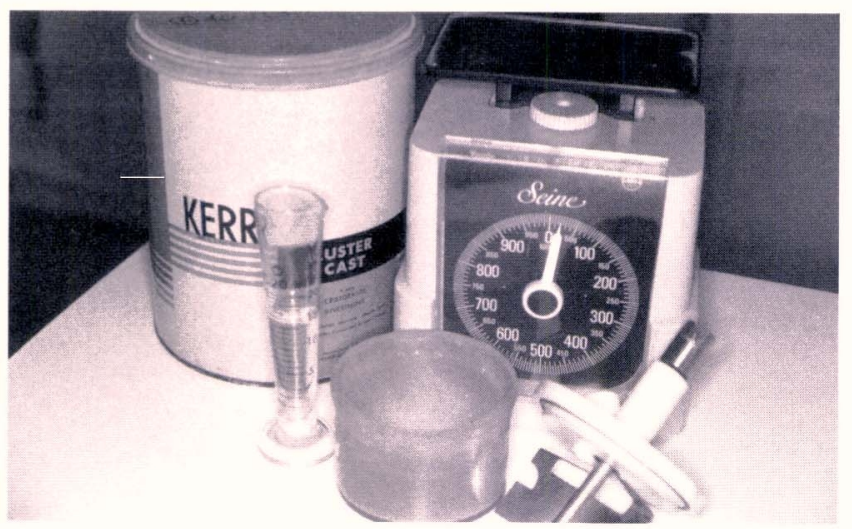

図 己 埋没材は, 必ず液・粉比を測って使用する 


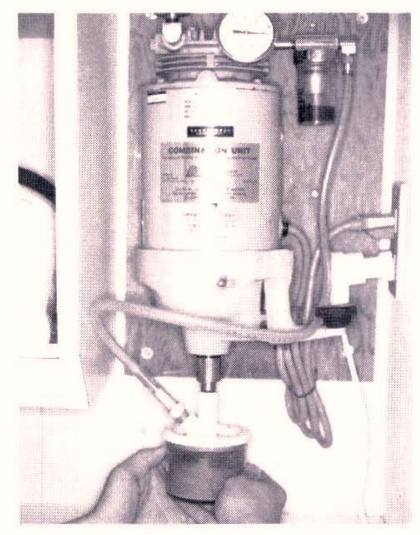

図 3 埋没材は必ず真空擋找する

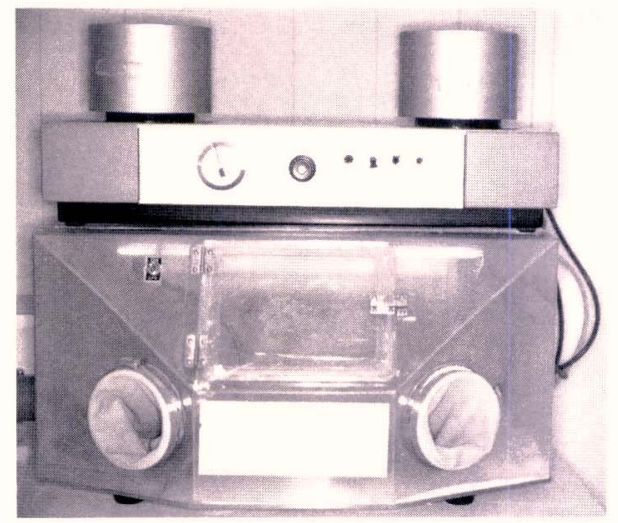

図 5

コムコ社の
マイクロブ ラスター

\section{3. 鋳 造}

埋没材には以前はKERR社のラスターキャストを使って 埋没していた. 水 $17 \mathrm{~m} l$ に粉 $50 \mathrm{~g}$ で真空擋拌して埋没する.

この埋没材はクリストバライト系の埋没材で, 中に岑素 の粉が入っていて，鋳造時に金属が酸化されにくく配虑さ れている。このラスターキャストをはじめとして，従来の 埋没材は硬化に時間がかかり，さらに電気炉に入れてから 鋳造できるようになるまで大変時間がかかった。そこで今 では GC社クリストクイック II を使うようになった。混水比 は水 $33 \mathrm{~m} l$ に粉 $100 \mathrm{~g}$ であるが, $5.5 \mathrm{~cm}$ の鋳造リングでは埋 没材 $40 \mathrm{~g}$ に対して水 $13.2 \mathrm{~m} /$ にして練和すると，ちょうどよ い分量となる，埋没材練和と同時に炉のスイッチを「 $\mathrm{ON}\rfloor$

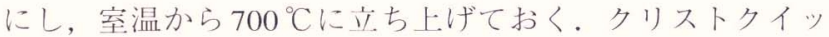
ク II は練和開始から 30 分で硬化するので，その時点で炉 の中に人れて焼成を開始することができる。また炉内は室 温から $700{ }^{\circ} \mathrm{C} に$ 達するのに 30 分かかるので，埋没材練和と 炬のスイッチを入れるタイミングを同時にするのである。 $700{ }^{\circ} \mathrm{C}$ に達したらリングを炉に入れ，そのままで 30 分間係 留して焼成する。つまり，埋没老始めてから，合計 60 分 で鋳造できることになる、鋳造機内の炭素棒の中で金属を 溶かしリングをセット後，機内を真空状態にして反転すれ ば,物理的に引力の法則により金属が流れて鋳造ができる.

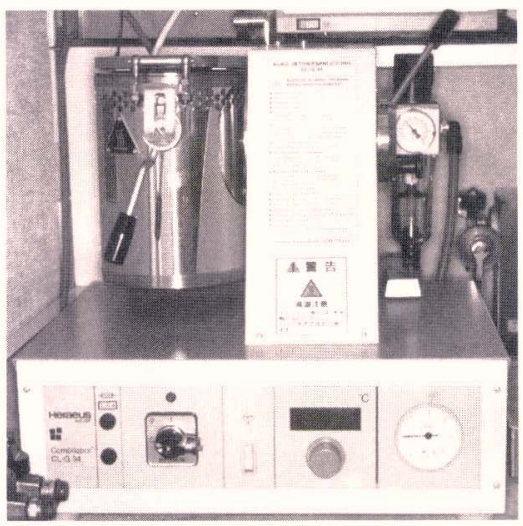

図4 鋳造理論にかなっ た, ヘラウスクル ツアー社の真空圧 迫鋳造機

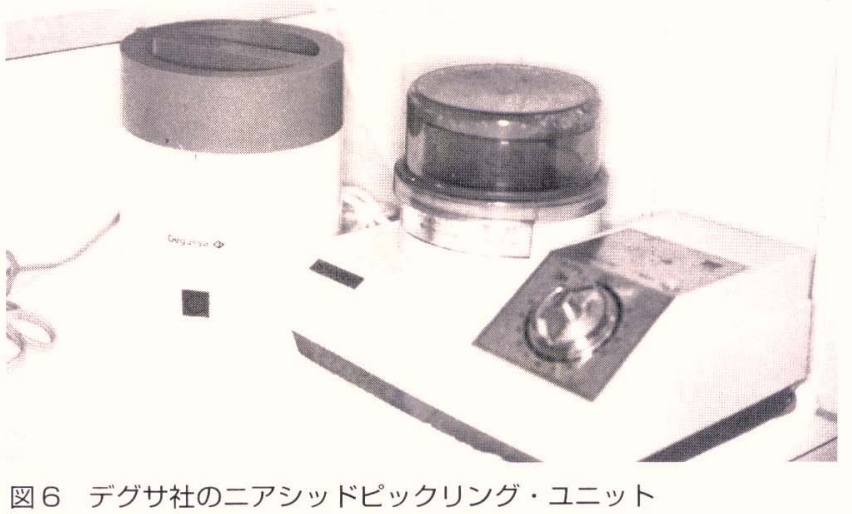

\section{4. 鋳造が終わったら}

鋳造で大切なことは金属がよい状態になっている，とい うことである。溶けた金属の中に異物が入り込んだり，金 属を溶かしている最中に，酸化を促進する方法で行ったり するようでは金属のためによくない。このようなことにな らない，鋳造システムの鋳造機を使う必要がある。そうす れば，常に劣化していない金属老使えることになるからで ある。そのために炭素棒の中で金属を溶かし，真空状態の 中で鋳造を行い，鋳造が終わった直後に空気を入机て全体 に強圧をかけ，鋳造を隅々まで行き渡らせながら鋳造密度 を濃くするよう心がけているのである。こうして鋳造され た金属は，細部まで再現された表面のきれいな鋳造体であ り，その付け根のボタン部分の金属の形は大变特徴がある. 一般的に遠心鋳造で行った場合のボタンは,ペシャッと潰 されたような形をしているが，この真空圧迫鋳造機の場合 には，お団子のように丸い形になるのである。さて，鋳造 が済んだら鋳造体の周りの埋没材などをサンドブラスター できれいに除去する。その後，デグサ社のニアシッドピッ クリング・ユニットの中に入れ，金属の表面清掃および金 属表面の酸化膜除去をする。これらの仕事は大変大切なこ とで，せっかく金属を酸化させないような鋳造システムで やっていることであるから，常に手は抜けないのである. 


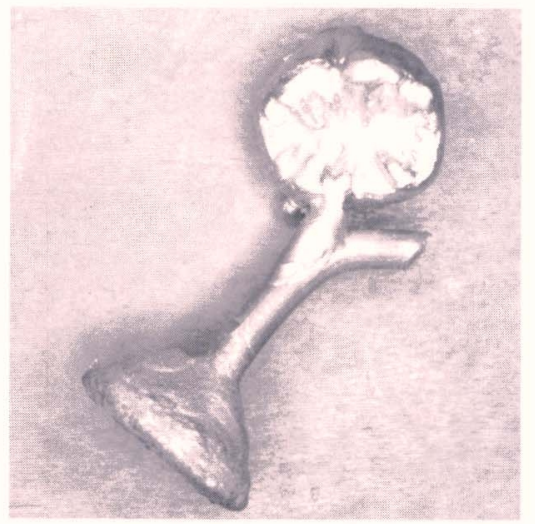

図 7 真空圧迫鋳造機で 鋳造された形

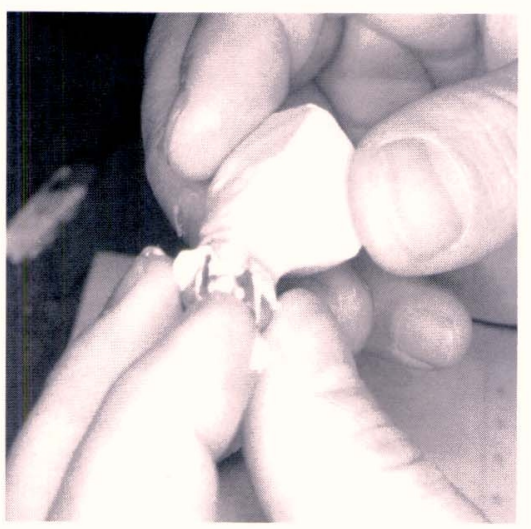

図 9 副模型上でフィッ トチェッカーを使 い, 內面調整

\section{5. 鋳造体からクラウン修復物へ}

酸化膜を取った後の鋳造体を見てもらいたい。真空圧迫 鋳造機で鋳造された形である, 独特のボタンの形, $3 \mathrm{~mm}$ 線 の太いスプルーの形,表面が滑らかできれいな鋳造体,これ だから真空圧迫鋳造機は素晴らしいのである。ここで鋳造 体からクラウン部分を離す作業を最初に行うのであるが， 切断にはエンゲルハート社のセパレーティング・ディスク かウルトラスイン・ディスクを使って，クラウンの根元か らカットする．このクラウンのマージンは大変デリケート な再現性の形にできあがっているため，クラウン部分を飛 ばして転がしたり，床に落としたりしないような注意深い 配慮が必要である。もし技工作業の最中に鋳造体を床に落 としたならば，ばりのように薄く繊細に再現されている鋳 造体のマージンは内側に曲がってしまい，副模型にも，本 模型にもきっちりした適合が得られなくなってしまうので ある、そのため鋳造体を切断するときには，必ずクラウン 部分を持って行うように心がけ，決してボタン部分を持っ て切断してはいけないのである。ましてやニッパーで思い つきり切断するようなことは，スプルー線が細くても太く ても絶対にしてはいけないのである。また鋳造体のチェッ クとして,マージン部分のベベルの先端が精確に, 忠実に再 現されているかどうかも確認しておかなければならない.
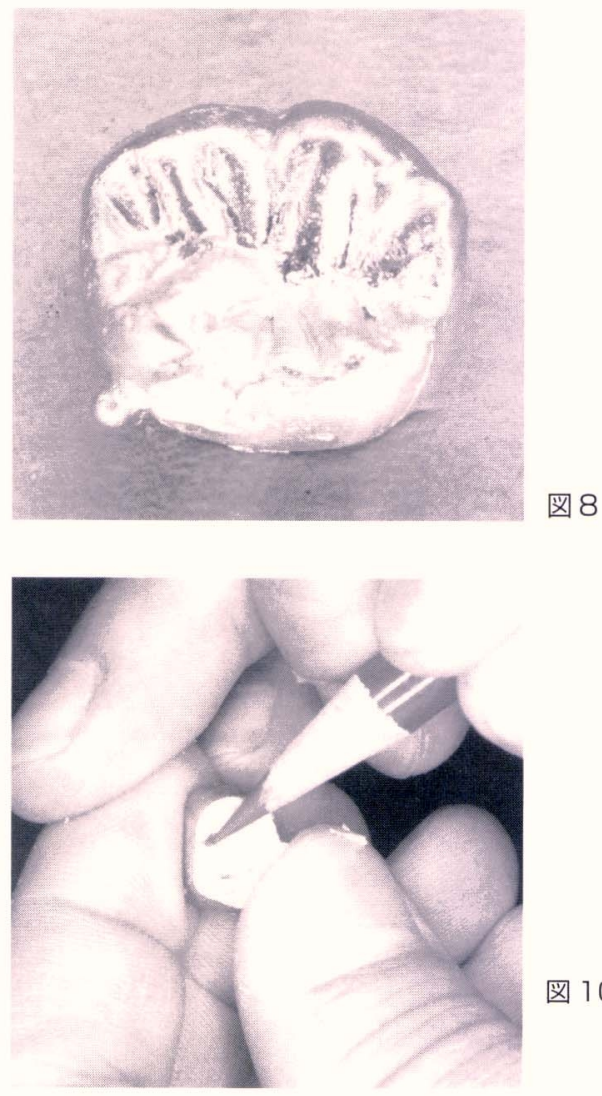

図 10 金属の露出して いる場所を赤鉛 筆でマークする

\section{6. そっと副模型に合わせてみる}

さあ，そうしたら最初にクラウン内面や模型表面に何も 付けていない状態で，そーっと副模型とクラウンを適合さ せてみよう。今までの技工操作の中でお話ししたような手 順を踏んで行われていれば，問題になるような狂いはほと んどなく，鋳造体はすっと副模型に収まるだろう。もし収 まりがよくないのであ机，内面にプラスの気泡があるの かもしれない。いずれにしても，最初の副模型への適合を チェックしたら，技工室用のマイクロスコープで鋳造体ク ラウンの内面を，注意深く見ていくのである。そうすると， ワックスアップしたときのワックスの継ぎ目が無数のしわ または亀裂や穴となっており，その中にまだ取り残された 埋没材が大きな岩のように塊となってこびりついているの が見えるだろう。それとも，無数の小さなボール球がこび りついているのが見えるかもしれないし，大きな玉が角の ところについているかもしれない。クラウン内面がしわや 波のように見えたら，ワクシングの腕をもっと磨こう。内 面全体に小さな玉が無数についているのであれば，真空擋 拌機が正確に作動しているか千ェックしてみよう。いずれ にしても確認のできたものはマイクロスコープ下で丹念に 削り取っておこう。これで肉眼で見える範囲のものを除去 したので，後はフィットチェッカーを使い，千ェックする. 


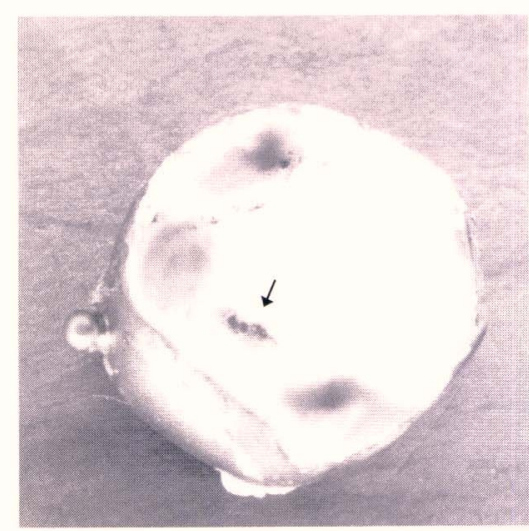

図 11 フィットチェッ カーを剥がし 赤マーク (矢印) の場所を削合す る

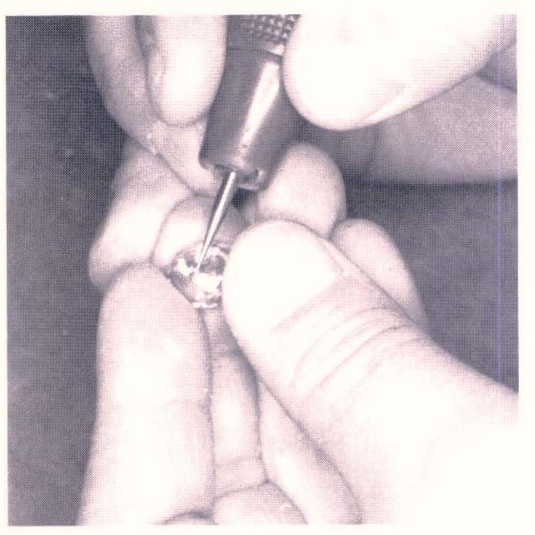

図 13 咬合面の調整

\section{7. フィットチェッカーで内面調整}

どんなに膨張や収縮誤差の少ないワックスや埋没材を使 っても，できあがった鋳造体はその䛊差がまったくゼロで あるなどということはまったくありえないことであり， 鋳造体をまったく調整せずに模型にはめることは理想であ って現実ではありえない。そこで鋳造体の内面で，些細な 䛊差による小さな变形を見つけて調整するために，フィッ トチェッカーを使っていくのである。クラウンの内面をチ エックするのに模型にスペーサーまがいに厚く色物を塗つ たり，クラウンの内面に塗ったりするものもあるが，模型 をいためずに本来の形のままで仕事をするためには，スペ ーサーのようなものは使う必要がないはずである。フィッ トチェッカーを使うときには，クラウン内面を濡らしてか ら内面に盛らないと, あとでフィットチェッカーが取り去 りづらいので要注意。また副模型に装着するときには，力 を入机てきゅっとはめ込んではいけない，いくら超硬石膏 のベルミックスストーンでも，力を人れて押せば模型がこ すれて最後のところまで入ってしまう。あくまでも力を入 れず，そっと副模型に入れてみるのである。最終的には副 模型の形成限界とクラウンのマージンがぴったりついてく るようになるはずであるから, その間の䛊差は金属の露出 した内面の調整を繰り返すことで, 合わせていくのである.

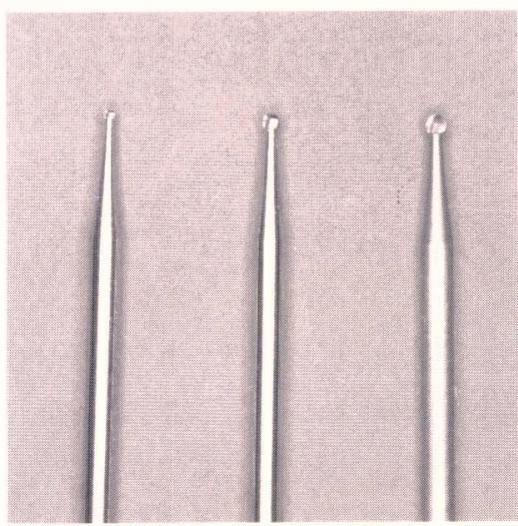

図 12 エメスコ社カー バイドのラウン ドバー\# 1, \#3, \#5

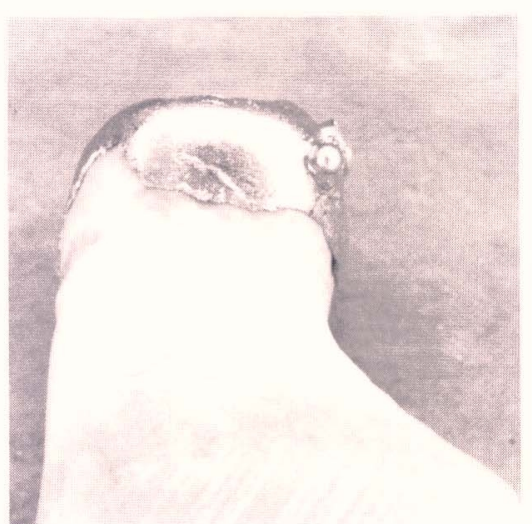

図 14

\section{8. 咬合面の調整}

内面の削合には, 通常, エメスコ社のカーバイドのラウ ンドバーを使っている。この\#1，\#3，\#5の大きさのラウ ンドバーを使い分けるのである。軸壁面の広い面積の場所 や，大きな気泡のようなものであ机ば\# 5 の大きなラウン ドバーで削り，軸壁と咬合面との間の隅角部分やグルーブ の脇のような場所の削合には, 小さな\#1ラウンドバーを使 っている、いず机しても,カーバイドのラウンドバーは大 変切机味がよく, いつまでも切机味が落ちないので大变重 宝している。さて内面の調整が終わり, 副模型の形成限界 上に引いた赤鉛筆の線のところまでクラウンのマージンが 届き，フィットチェッカーが薄い皮膜のような顔つきの薄 さになったら, 内面調整は終了。これから次に, 本模型上 での仕事をするのであるが，その前に咬合面の溝の形態の み仕上げておくとよい。この溝には小さな気泡がついてい るかもしれないし，咬合面の顔つきがはっきりしていない かもしれない, 今後, 本模型上で咬合の千エックをし, 場合 によっては咬合調節をしなければならないのであるが，そ のとき咬合面に気泡がついたままでチェックしていたので は, 意味がない.そのため, 一番小さな $1 / 4$ のラウンドバー 老使って主溝も副溝も丹念に溝をつけていく。このように することで，後の仕事が楽に行えるようになるのである。 